\title{
Correlation Between Iodine Status and Dysfunctional Parameters of the Thyroid Gland of Djidja Schoolchildren
}

\section{Alphonse S. Avocefohoun, MSc}

Laboratoire de Biologie et de Typage Moléculaire en Microbiologie, Faculté des Sciences et Techniques/Université d'Abomey-Calavi, Cotonou, Benin.

\section{Bertin A. Gbaguidi, PhD}

Laboratoire de Biomembranes et de Signalisation Cellulaire, Département de

Physiologie Animale, Faculté des Sciences et Techniques, Université

d'Abomey- Calavi, Cotonou, République du Benin

\section{Haziz Sina, PhD}

Laboratoire de Biologie et de Typage Moléculaire en Microbiologie, Faculté des Sciences et Techniques/Université d'Abomey-Calavi, Cotonou, Benin.

\section{Olivier Biaou, PhD}

Faculté des Sciences de la Sante, Université d'Abomey-Calavi, Benin

\section{Adolphe Adjanohoun}

Centre de Recherches Agricoles Sud, Institut National des Recherches Agricoles du Bénin (INRAB), Cotonou, Bénin

\section{Christophe S. Houssou, PhD}

Faculté des lettres, Arts et Sciences Humaines, Université d'Abomey-Calavi, Benin

\section{Lamine Baba-Moussa, PhD}

Laboratoire de Biologie et de Typage Moléculaire en Microbiologie, Faculté des Sciences et Techniques/Université d'Abomey-Calavi, Cotonou, Benin.

Doi: 10.19044/esj.2018.v14n3p86 URL:http://dx.doi.org/10.19044/esj.2018.v14n3p86

\begin{abstract}
Iodine is reported to be one of the main trace mineral constituting thyroid hormones. The aim of this study was to determine the correlation between urinary iodine concentration status and dysfunctional parameters of the thyroid gland of schoolchildren in central Benin. In our study we selected 108 schoolchildren to whom we performed T3, T4, TSH, iodine and thyroid volume tests. The determination of the morning urinary iodine (iodine) in Djidja schoolchildren gave satisfactory results to $72 \%$ thus declaring our study area as a zone of non-iodine dietary deficiency. The hormone assay results are favorable at a rate of $92 \%$ and corresponds to hypothyroidism. In fact, TSH
\end{abstract}


are high in $85 \%$ of the study population, T3 are in their case low in $93 \%$ of our study population and finally T4 are lower in the $100 \%$ of individuals in the study population. But these results are not in agreement with the iodine obtained. Indeed, in the study environment, the population is forced to drink some water rich in fluoride. Fluorine is an iodine antagonist that it can easily substitute, disrupting the production of T3, T4 and TSH hormones. To end, the calculated thyroid echography volumes are for the most part normal volumes with a rate of 45.37 for boys and 35.19 for girls.

Keywords: Iodine, Hormones, Fluorine, Ultrasound volume, Schoolchildren, Benin

\section{Introduction}

Iodine is an essential nutrient found in the human body as a key component of the thyroid hormones, thyroxine (T4) and triiodothyronine (T3). So, according to Stangubgy (1992), iodine is a principal trace element constituting thyroid hormones. These thyroid hormones regulate cellular oxidation, energy metabolism, and the basal metabolic rate, and are critically important for neurological growth and development, particularly during gestation and early infancy (Rohner et al., 2014; Skeaff, 2011). It is reported that a low intake in iodine is associated with several negative health effect affecting about 2 million people worldwide and generically named iodine deficiency disorders (Zimmermann et al., 2012). One of the most important iodine disorder is hypothyroidism and goiter (enlarged thyroid gland). This is the result of excessive secretion of thyroid stimulating hormone in response to low levels of circulating $\mathrm{T} 4$ resulting in an overactive thyroid gland (Zimmermann and Boelaert, 2015; Rohner et al., 2014; Zimmermann et al., 2008). Those disorder negatively affect the productivity of the one suffering and is known to be one of the most common preventable causes of mental retardation (ICCIDD, 1999; WHO, 2007). This study was undertaken in order to determine the correlation between urinary iodine concentration status and dysfunctional parameters of the thyroid gland of schoolchildren in central Benin.

\section{Material and Methods \\ Study area and Sampling}

Our study was conducted in southern Benin precisely at Djidja $\left(7^{\circ} 20^{\prime} 40^{\prime \prime}\right.$ North, 1 ${ }^{\circ} 56^{\prime} 00^{\prime \prime}$ Est) (Figure 1). The study population was composed of children age from 6 to 13 years, born in the municipality and had lived there since birth and attending primary schools (Hanagbo, Dridji, Assegon and Akazounnongon). The study population was the same to those reported in a previous study (Avocefohoun et al., 2017). 


\section{Data collection}

A fasting single spot urine sample $(\sim 2 \mathrm{~mL})$ was collected from children in the morning from each of the selected students from the 4 primary schools. Children were instructed to void their bladders in the morning before beginning the 24-h urine sample, and spot urine samples were taken from the first morning urine. Once collected, urine samples were transported on ice $\left(4^{\circ} \mathrm{C}\right)$ from the schools to the Laboratory and immediately analyzed or stored at $-80^{\circ} \mathrm{C}$ until analysis. Age, sociodemographic and other data were collected using a questionnaire prepared and administered for the study. Urinary iodine concentrations were determined using ammonium persulfate digestion followed by colorimetric analysis based on the Sandell-Kolthoff (Sandell and Kolthoff, 1937) reaction according to a modified microplate method (Ohashi et al., 2000).

Venous blood samples were collected from the same children's and were taken from the cubital veins into vacutainers. The collected blood was allowed to coagulate at room temperature, before the sera were separated by centrifugation and kept at $4{ }^{\circ} \mathrm{C}$ for $24 \mathrm{~h}$ or $-20^{\circ} \mathrm{C}$ until analysis.

Serum triiodothyronine (T3) and free thyroxine (FT4) were measured with solid phase time-resolved fluoro-immunoassays (TR-FIA). The reference range for T3 is $4-8.3 \mathrm{pmol} / \mathrm{L}$ and for FT4 is $10-19.4 \mathrm{pmol} / \mathrm{L}$. TSH was measured with a sandwich TR-FIA and classified as euthyroid $(0.25 \mu \mathrm{U} / 1<$ $\mathrm{TSH}<5 \mu \mathrm{U} / \mathrm{l})$, hyperthyroid $(\mathrm{TSH}<0.15 \mu \mathrm{U} / \mathrm{l})$ or hypothyroid $(\mathrm{TSH}>7 \mu \mathrm{U} / \mathrm{l})$.

The thyroid size was determined by ultrasonography. Thus, the longitudinal and transverse scans are performed allowing the measurements of the depth (d), the width (w) and the length (l) of each lobe. The volume (V) of the lobe is calculated by the formula: $\mathrm{V}(\mathrm{ml})=0.479 \times \mathrm{d} \mathrm{x} \mathrm{w} \times 1(\mathrm{~cm})$. The thyroid volume is the sum of the volumes of both lobes. The volume of the isthmus is not included.

The body surface area (BSA) is calculated using the formula of Dubois and Dubois (1989): BSA $\left(\mathrm{m}^{2}\right)=\mathrm{W}^{0.425} \times \mathrm{H}^{0.725} \times 71.84 \times 10^{-4}$. It should be emphasized that by using the ultra-sonographic criteria, a thyroid gland will be called goitrous when its values will be above the $97^{\text {th }}$ percentile of the volume found in an iodine replete population used as control.

\section{Data analysis}

The collected data were coded, captured and processed with SPSS 20.0 (Norusis, 2002) for the determination of descriptive statistics in terms of percentage and average. As for the quantitative data, they were subjected to ANOVA using the ANOVA procedure of the SAS 9.2 to assess the gap between girls and boys. Multiple mean comparisons were made with the Student Newman-Keuls test (Dagnelie, 2012). The different correlations of 
Person were made with the Minitab 14 software. The results of the different analyzes are presented in the form of tables according to Kisauzi et al. (2012).

\section{Results}

\section{General condition of the study}

The analysis of the surveyed population size (Table 1) and the results of the analysis of the variance and the Student Newan Keuls test (Table 2) shows that the boys dominate the surveyed population with a percentage of $57 \%$ but the difference of proportion was not significant in terms of age, height, weight, body surface area and body age ( $\mathrm{p}>0.05)$.

Table 1. Number of people surveyed

\begin{tabular}{ccc}
\hline Modality & Proportion of Population $(\mathrm{N})$ & Samples proportion $(\mathrm{N})$ \\
\hline Boys & $56.74(320)$ & $57.40(62)$ \\
Girls & $43.26(240)$ & $42.60(46)$ \\
TOTAL & $100(560)$ & $100(108)$ \\
\hline
\end{tabular}

Table 2. Analysis of variance performed on the quantitative data

\begin{tabular}{llll}
\hline \multirow{2}{*}{ Parameters } & \multicolumn{1}{c}{ Bex } & \multirow{2}{*}{ P-value } \\
\cline { 2 - 3 } \cline { 2 - 3 } Age (years) & \multicolumn{1}{c}{ Boys } & \multicolumn{1}{c}{ Girls } & \\
Length (m & $1,30 \pm 0,23 \mathrm{a}$ & $9,28 \pm 0,29 \mathrm{a}$ & 0,4157 \\
Weight & $25,05 \pm 0,96 \mathrm{a}$ & $1,30 \pm 0,02 \mathrm{a}$ & 0,9924 \\
Body surface area & $1510,36 \pm 0,98 \mathrm{a}$ & $24,15 \pm 1,06 \mathrm{a}$ & 0,5363 \\
V R & $1587,09 \pm 77,29 \mathrm{a}$ & $1509,46 \pm 1,08 \mathrm{a}$ & 0,5419 \\
V L & $1523,31 \pm 76,37 \mathrm{a}$ & $1573,13 \pm 86,94 \mathrm{a}$ & 0,9052 \\
V (V L+VR) & $3110,40 \pm 143,24 \mathrm{a}$ & $3164,34 \pm 87,26 \mathrm{a}$ & 0,5604 \\
Iodine & $216,45 \pm 30,51 \mathrm{a}$ & $284,78 \pm 45,14 \mathrm{a}$ & 0,8036 \\
TSH & $7,00 \pm 0,27 \mathrm{a}$ & $7,04 \pm 0,27 \mathrm{a}$ & 0,1959 \\
T4 & $3,02 \pm 0,18 \mathrm{a}$ & $3,02 \pm 0,24 \mathrm{a}$ & 0,9238 \\
\hline
\end{tabular}

The averages followed by the same alphabetical letters of the same characters and for the same characteristics are not significantly different ( $p$ > $0.05)$ according to the Student Newman test -Keuls

\section{Iodine content determined on subjects and relationship with physical parameters} urine.

Table 3 shows the different standards for the iodine rate analyzed on

The analysis of urinary iodine content (UIC) shows that the majority of surveyed students (51\%) do not suffer from iodine deficiency (Table 3). Additionally, iodine levels obtained do not vary significantly among age groups. However, people with high body surface area are less iodine deficient compared to others $(47 \%)$. The Person correlation between iodine levels and physical parameters (age, weight, body surface area) measured on students shows that no significant correlation is obtained between iodine and these 
physical parameters ( $\mathrm{p}>0.05$ ). Iodine levels therefore do not depend on sex, body size, and body surface area.

Table 3. Iodine content measured on the surveyed students

\begin{tabular}{|c|c|c|c|c|c|c|}
\hline \multirow[t]{3}{*}{ Categories } & \multicolumn{6}{|c|}{ Parameters } \\
\hline & \multicolumn{2}{|c|}{ Sex } & \multicolumn{2}{|c|}{ Age (years) } & \multicolumn{2}{|c|}{ Body surface area (BSA) } \\
\hline & Boys & Girls & $0<$ age $<10$ & Age $>10$ & $\mathrm{BSA}<1500$ & $\mathrm{BSA}>1500$ \\
\hline $\begin{array}{c}\text { UIC }<20 \mu \mathrm{g} / \mathrm{l} \text { (severe } \\
\text { deficiency) }\end{array}$ & $13.89 \%$ & $4.63 \%$ & $08.33 \%$ & $10.19 \%$ & $02.78 \%$ & $15.74 \%$ \\
\hline $\begin{array}{l}20<\mathrm{UIC}(\mu \mathrm{g} / \mathrm{l}) \leq 49 \\
\text { (moderate deficiency) }\end{array}$ & $0 \%$ & $0 \%$ & $0 \%$ & $0 \%$ & $0 \%$ & $0 \%$ \\
\hline $\begin{array}{c}50<\mathrm{UIC}(\mu \mathrm{g} / \mathrm{l}) \leq 99 \\
\text { (slight deficiency) }\end{array}$ & $03.70 \%$ & $02.78 \%$ & $02.78 \%$ & $03.70 \%$ & $0 \%$ & $06.48 \%$ \\
\hline $\begin{array}{c}100<\text { UIC }(\mu \mathrm{g} / \mathrm{l}) \leq \\
300 \text { (No iodine } \\
\text { deficiency) }\end{array}$ & $27.78 \%$ & $23.15 \%$ & $26.85 \%$ & $24.07 \%$ & $03.70 \%$ & $47.22 \%$ \\
\hline $\begin{array}{c}\mathrm{UIC}>300 \mu \mathrm{g} / \mathrm{l} \\
\text { (excess of iodine) }\end{array}$ & $09.26 \%$ & $12.04 \%$ & $07.41 \%$ & $13.89 \%$ & $0 \%$ & $21.30 \%$ \\
\hline
\end{tabular}

\section{Hormone levels determined on students}

Table 4 presents the results of the hormones measured. This table shows that the majority (55\%) of the students involved in this study are hypothyroid with a T3 level below $4 \mathrm{pmol} / \mathrm{l}$ and a T4 below $10.6 \mathrm{p} \mathrm{mol} / \mathrm{l}$. Similarly, subjects with a body surface area greater than 1500 are main part $(85 \%)$ of this category of hypothyroid.

Table 4. Hormone level recorded according the sex, age and body surface area.

Parameters

\begin{tabular}{|c|c|c|c|c|c|c|c|}
\hline & \multirow[t]{2}{*}{ Categories } & \multicolumn{2}{|c|}{ Sex } & \multicolumn{2}{|c|}{ Age (years) } & \multicolumn{2}{|c|}{ Body surface area (BSA) } \\
\hline & & Boys & Girls & $0<$ age $<10$ & Age $>10$ & $\mathrm{BSA}<1500$ & $\mathrm{BSA}>1500$ \\
\hline \multirow{3}{*}{ 党 } & $<0.25 \mu \mathrm{UI}$ & $0 \%$ & $0 \%$ & $0 \%$ & $0 \%$ & $0 \%$ & $0 \%$ \\
\hline & $0.25-5 \mu \mathrm{UI} / \mathrm{l}$ & $08.33 \%$ & $06.48 \%$ & $06.48 \%$ & $02.85 \%$ & $0 \%$ & $12.96 \%$ \\
\hline & $>5 \mu \mathrm{UI} / 1$ & $49.08 \%$ & $36.11 \%$ & $37.96 \%$ & $53.71 \%$ & $06.48 \%$ & $80.56 \%$ \\
\hline \multirow{3}{*}{$\Leftrightarrow$} & $<4 \mathrm{pmol} / \mathrm{l}$ & $63.89 \%$ & $29.63 \%$ & $42.59 \%$ & $57.41 \%$ & $06.48 \%$ & $93.52 \%$ \\
\hline & $4-8.3 \mathrm{pmol} / \mathrm{l}$ & $02.78 \%$ & $02.78 \%$ & $0 \%$ & $0 \%$ & $0 \%$ & $0 \%$ \\
\hline & $>8.3 \mathrm{pmol} / \mathrm{l}$ & $0.93 \%$ & $0 \% \%$ & $0 \%$ & $0 \%$ & $0 \%$ & $0 \%$ \\
\hline \multirow{3}{*}{ 艺 } & $<10.6 \mathrm{pmol} / 1$ & $56.48 \%$ & $43.52 \%$ & $55.56 \%$ & $44.45 \%$ & $6.48 \%$ & $93.52 \%$ \\
\hline & $\begin{array}{c}10.6-19.4 \\
\mathrm{pmol} / \mathrm{l}\end{array}$ & $0 \%$ & $0 \%$ & $0 \%$ & $0 \%$ & $0 \%$ & $0 \%$ \\
\hline & $>19.4 \mathrm{pmol} / 1$ & $0 \%$ & $0 \%$ & $0 \%$ & $0 \%$ & $0 \%$ & $0 \%$ \\
\hline
\end{tabular}

The thyroid volume values (VT) recorded among the investigated students shows that the majority of the students are in the standards (Table 5). Similarly, students older than 10 years and Body surface area less than 1500 are still present in the standard.

Table 5. Presentation of thyroid volume values by sex, age and body surface area 


\begin{tabular}{|c|c|c|c|c|c|c|c|}
\hline & & \multicolumn{2}{|c|}{ Sex } & \multicolumn{2}{|c|}{ Age (years) } & \multicolumn{2}{|c|}{ Body surface area (BSA) } \\
\hline & & Boys & Girls & $0<$ age $<10$ & Age $>10$ & $\mathrm{BSA}<1500$ & $\mathrm{BSA}>1500$ \\
\hline \multirow{3}{*}{$\stackrel{\infty}{0}$} & $<1.80 \mathrm{ml}$ & $06.48 \%$ & - & $06.48 \%$ & $0 \%$ & $01.85 \%$ & $04.63 \mathrm{v}$ \\
\hline & $1.80-4.60 \mathrm{ml}$ & $45.37 \%$ & - & $20.37 \%$ & $25.00 \%$ & $0.93 \%$ & $44.44 \mathrm{v}$ \\
\hline & $>4.60 \mathrm{ml}$ & $05.56 \%$ & - & $0 \%$ & $05.56 \%$ & $04.63 \%$ & $0.93 \mathrm{v}$ \\
\hline \multirow{3}{*}{$\stackrel{n}{i}$} & $<1.99 \mathrm{ml}$ & - & $05.56 \%$ & $05.56 \%$ & $0 \%$ & $01.85 \%$ & $10 \mathrm{v}$ \\
\hline & $1.99-5.22 \mathrm{ml}$ & - & $35.19 \%$ & $15.74 \%$ & $19.45 \%$ & $01.85 \%$ & $33.33 \%$ \\
\hline & $>5.22 \mathrm{ml}$ & - & $01.85 \%$ & $0 \%$ & $01.85 \%$ & $0 \%$ & $01.85 \%$ \\
\hline
\end{tabular}

\section{Discussion}

Our research target 560 schoolchildren (56.74\% of boys and $43.26 \%$ girls) of the district of Djidja in Central Benin (West Africa). After the first investigation of the visible effect of fluorosis, 108 school children composed of boys $(57.40 \%)$ and girls $(42.60 \%)$ were finally retained as study sample. It appears that the boys are in the majority, however, the boy-girl relationship has been maintained in the same proportion as well in the initial population as in the study population. Our observation corroborate those reported by Djossou et al. (2017) in a similar study on the link between fluorosis and sex. However, the difference remains not significant. But considering goiter, the prevalence shows that girls are more affected than boys (Malbossbaf et al., 2013).

The analysis of variances for anthropometric factors and other data such as iodine, T4, T3, TSH and TV shows no significant difference. In addition, the iodine analysis of the urines among our study population shows that $51 \%$ of investigated schoolchildren were in the standards $(100-300 \mu \mathrm{g} / \mathrm{l})$ recommended by WHO. This proportion include both boys ( $28 \%$ of the total) and girls (23\%). It was observed that $21 \%$ of the investigated population shows an excess of iodine. Globally, the iodine test in urines is satisfactory at $72 \%$ and according to the recommendations of WHO, we can declare that our study area is a zone of non-dietary iodine deficiency. As previously reported in Abomey-Calavi, Southern Benin (Gbaguidi et al., 2013), Djidja in the center of the country is also non-dietary iodine deficiency. In fact, in their study on the status in the district of Abomey-Calavi where 134 schoolchildren were surveyed, the results showed that $92.28 \%$ of schoolchildren from 6 to 12 years old had normal iodine rate.

Thought the global status of the area is good, it should be noted that cases of excess iodine are on some schoolchildren in Djidja (21\%) do not reassure the health situation of those children. This could occur in a Wolf Chaikoff effect exposure situation (Wolf and Chaikoff, 1948) that could plunge into thyroid dysfunction states with the support of adverse effects and complications. It was observed a very significant difference in school children with a body surface area greater than 1500 in which the proportion of normal 
results was $68 \%$ of the investigated population for iodine status. The status is mainly justified by the fact that Djidja is a district where subsistence farming is practiced on a large scale despite the expansion of cotton production. In addition, Djidja is the breadbasket of Zou (a department located in central Benin) with a strong capacity for diversification of foodstuffs. So, according to MPDEPPCAG (2010), food consumption patterns in Benin are mainly determined by agro-ecological zones and the level of urbanization.

These results of iodine are not in adequacy with the TSH, T3 and T4 hormonal results observed. Indeed, in the surveyed population $85 \%$ of the schoolchildren displays a TSH level higher than normal $(0.25$ - $5 \mathrm{UI} / \mathrm{l})$ while the dosage of T3 reveals a positive result with $93 \%$ less than $4 \mathrm{pmol} / 1$ and the assay of T4 has a positive result with almost $100 \%$ less than $10.6 \mathrm{pmol} / \mathrm{l}$. These results allow us to conclude that the schoolchildren surveyed develop hormonal disorders deficiency (hypothyroidism). According to Masson (2014) the thyroid hormones are tri-iodothyronine (T3) and tetra-iodothyronine (T4) secreted from the food hormone and regulated by a pituitary hormone, thyrotropulin (TSH), secreted in turn by a gland located on the underside of the brain. Under these conditions the results given by iodine allow to have regular hormonal secretions. Indeed, in a previous work, we studied the prevalence of fluorosis in drinking water consumption by Djidja schoolchildren (Avocefohoun et al., 2017). The analysis of drinking water revealed that these waters are rich in fluoride. In its 2006 report, the National Research Council on National Academies states that fluoride is an endocrine disruptor in the broad sense of normal endocrine function (National Research Council, 2006; Cornet et al., 2010). According to Hetzeil (1983), this impaired function may involve the thyroid gland, parathyroid gland, pineal glands as well as the adrenal glands, the pancreas and the pituitary gland. The consequence is the replacement of the iodine molecules by fluorine. Indeed, fluorine, extremely negative element in the classification of Mendelev is an antagonist of iodine (Bürgi et al., 1984).

Results on thyroid ultrasound volumes show that the majority of school children have normal thyroid echography volume with $45.37 \%$ in boys and $35.19 \%$ in girls. This is consistent with the result of iodine achieved. But in Japan Fuse et al. (2007) found extreme volumes ranging from 0.8 to $8.5 \mathrm{ml}$, although conditions are almost identical to iodine or iodine status. This difference may be due to the phonotypical difference among our study population and Japanese. Similarly, in Belgium, Delange et al. (2000) found in their study that the size of the thyroid increased with age and the prevalence of goiter increased from 3.9 in children aged 6 to 11.7 children 12 years old. 


\section{Conclusion}

In our study we found that the iodine status observed at Djidja with a $72 \%$ appreciation of satisfactory morning iodine results did not agree with the thyroid function test results of the schoolchildren sampled. These school children present the results of T3, T4 and TSH of anyone developing hypothyroidism. This is justified by the substitution of iodine by an antagonistic substance, fluorine. On the other hand, the study of the thyroid echography volume reveals no significant difference. At $80 \%$ the thyroid echography volume of schoolchildren as boys is normal, which means that the substitution of fluorine for iodine does not have too much influence on the thyroid morphology.

\section{References:}

1. Avocefohoun, S. A., Gbaguidi, A. B., Sina, H., Biaou, O., Houssou, S. C, \& Baba-Moussa, L. (2017). Fluoride in Water Intake and Prevalence of Dental Fluorosis Stains among Children in Central Benin. International Journal of Medical Research \&Health Sciences, 6(12): 71-77.

2. Bürgi, H., Siebenhüner, L., \& Miloni, E. (1984). Fluorine and thyroid gland function: a review of the literature. Journal of Molecular Medicine, 62(12), 564-569.

3. Connett, P. H., Beck, J. S., \& Micklem, H. S. (2010). The case against fluoride: how hazardous waste ended up in our drinking water and the bad science and powerful politics that keep it there. Chelsea Green Publishing. Guest book review editorial Fluoride 43(3)170-173

4. Dagnelie, P. (2012). Statistique théorique et appliquée: compléments LOGICIEL R http://www.dagnelie.be/docpdf/stcompl.pdf

5. Delange, F., Van Onderbergen, A., \& Shabana, W. (2000). Silent iodine prophylaxis in Western Europe only partly corrects iodine deficiency, the case of Belgium. European Journal of Endocrinology, 143: 189-196.

6. Djossou, D., Djossou, A., \& Bigot, A. (2017). Chemical quality of ground waters and fluoride concentrations in the district of DassaZoume, Southern Benin. Academia Journal Scientific Research, 5(8): 218-223.

7. Du Bois D. \& Du Bois, E. F. (1989). A formula to estimate the approximate surface area if height and weight be known. Nutrition, 5(5): 303-311.

8. Fuse, Y., Saito, N., Tsuchiya, T., Shishiba, Y., \& Irie, M. (2007). Smaller thyroid gland volume with high urinary iodine excretion in Japanese schoolchildren: normative reference values in an iodine- 
sufficient area and comparison with the WHO/ICCIDD reference. Thyroid, 17(2):145-55.

9. Gbaguidi, B., Ahokpe, M., Yessoufou, G., Amoussou-Guenou, M., Houndonougbo, F., \& Sezan, A. (2013). Iodine Status and Goiter Prevalence in Schools in Abomey in Benin. International Journal of Multidisciplinary and Current Research, 1: 203-207.

10. Hetzeil B. S. (1983). Iodine deficiency disorders (IDD) and their eradication. Lancet, 2(8359): 1126-1129.

11. ICCIDD (1999). Global IDD status, IDD Newsletter, 15: 17-19.

12. Kisauzi, T., Mangheni, M. N., Seguya, H., \& Bashaasha, B. (2012). Gender dimensions of farmers' perceptions and knowledge on climate change in Teso sub-region, eastern Uganda. African Crop Science Journal, 20(2): 275-286.

13. Malboosbaf, R., Hosseinpanah, F., Mojarrad, M., Jambarsang, S., \& Azizi, F. (2013). Relationship between goiter and gender: a systematic review and meta-analysis. Endocrine, 43(3):539-547.

14. Masson, P. (2014). Désordres thyroïdiens et attitude de l'odontologiste. Thèse de doctorat d'Etat Université de Lorraine France, $111 \mathrm{p}$.

15. MPDEPPCAG (2010). Etude sur les normes de consommation des principaux produits vivriers au Bénin. Ministère de la Prospective, du Développement, de l'Evaluation des Politiques Publiques et de la Coordination de l'Action Gouvernementale, Centre de Partenariat et d'Expertise pour le Développement Durable et Bénin Consulting Group, République du Bénin.

16. National Research Council. (2006). Fluoride in Drinking Water: A Scientific Review of EPA's Standards. Washington, DC: The National Academies Press. https://doi.org/10.17226/11571.

17. Norusis, M. J. (2002). SPSS 11.0 Guide to Data Analysis. United States, Pearson, 637 pp.

18. Ohashi, T., Yamaki, M., Pandav, C. S., Karmarkar, M. G., \& Irie, M. (2000). Simple microplate method for determination of urinary iodine. Clinical Chemistry, 46(4): 529-536.

19. Rohner, F., Zimmermann, M., Jooste, P., Pandav, C., Caldwell, K., Raghavan, R., \& Raiten, D. J. (2014). Biomarkers of nutrition for development - iodine review. Journal of Nutrition, 144 (8), 1322S1342S.

20. Sandell, E. B., \& Kolthoff, I. M. (1937). Micro determination of iodine by a catalytic method. Mikrochemica Acta, 1(1):9-25.

21. Skeaff, S. A. (2011). Iodine deficiency in pregnancy: The effect on neurodevelopment in the child. Nutrients, 3 (2): 265-273. 
22. Stanburgy, J. B. (1992). Iodine and human development. Medical Anthropology, 13(4): 413-423.

23. WHO (2007). Assessment of iodine deficiency disorders and monitoring their elimination, A guide for program managers, Third edition. Geneva, Switzerland, 98 pp. http://apps.who.int/iris/bitstream/10665/43781/1/9789241595827_en g.pdf

24. Wolff, J., \& Chaikoff, I. L. (1948). Plasma inorganic iodide as a homeostatic regulator of thyroid function. Journal of Biological Chemistry, $174: 555-564$.

25. Zimmermann, M. B., \& Andersson, M. (2012). Update on iodine status worldwide. Current Opinion Endocrinology Diabetes and Obesity, 19 (5): 382-387.

26. Zimmermann, M. B., Jooste, P. L., Pandav, C. S. (2008). Iodinedeficiency disorders. Lancet, 372 (9645): 1251-1262.

27. Zimmermann, M.B. \& Boelaert, K. (2015). Iodine deficiency and thyroid disorders. Lancet Diabetes and Endocrinology, 3(4): 286-295. 